\begin{tabular}{|c|c|c|c|c|}
\hline Share: Social Work Jurnal & VOLUME: 9 & NOMOR: 1 & HALAMAN: 20-27 & $\begin{array}{c}\text { ISSN:2339-0042 (p) } \\
\text { ISSN: } 2528-1577(e) \\
\text { Doi: } 10.24198 / \text { share.v9i1.19863 }\end{array}$ \\
\hline
\end{tabular}

\title{
PERSEPSI MASYARAKAT TERHADAP PERCERAIAN Society Perception Of Divorce
}

\author{
Noeranisa Adhadianty Gunawan ${ }^{1}$, Nunung Nurwati \\ 1. Pascasarjana, Fakultas IImu Sosial dan IImu Politik, Universitas Padjaradjaran \\ noeranisaicha@gmail.com \\ 2. Program Studi Kesejahteraan Sosial, Fakultas IImu Sosial dan IImu Politik, Universitas Padjadjaran \\ nngnunwati@yahoo.co.id
}

\begin{abstract}
ABSTRAK
Perceraian merupakan terputusnya hubungan pernikahan yang telah diputuskan sesuai dengan hukum yang berlaku dan sudah berdasarkan kepada kesepakatan antara kedua belah pihak. Perceraian saat ini fenomena yang masih dianggap tabu oleh sebagian masyarakat, karena perceraian ini menandakan bahwa makna-makna yang terdapat dalam pernikahan tidak dijalankan dengan semestinya. Tujuan penulisan artikel ini adalah untuk mendeskripsikan persepsi masyarakat tentang permasalahan yang terjadi dalam keluarga sebagai pemicu perceraian dan untuk menganalisis persepsi masyarakat terhadap banyaknya kasus perceraian saat ini. Tulisan ini menggunakan pendekatan kualitatif dengan metode studi kasus, dengan pengumpulan data berupa wawancara dengan informan, penulusuran litelatur, dan studi dokumentasi. Hasil kajian menunjukkan bahwa sebagian masyarakat mempresepsikan perceraian sebagai sesuatu yang tidak baik, terutama kasus gugat cerai yang diajukan istri. Masih adanya label di masyarakat yang menunjukan bahwa perempuan harus berperan sesuai kodratnya, walaupun saat ini telah banyak perempuan yang bekerja di luar rumah. Masyarakat mengungkapkan bahwa seharusnya pernikahan harus dapat dipertahankan agar makna kesakralannya sendiri tetap terjaga.
\end{abstract}

Kata Kunci : Perceraian, Persepsi, Masyarakat

\begin{abstract}
Divorce is the disconnection of the marriage relationship that has been decided in accordance with the applicable law and has been based on an agreement between the two parties. Divorce is currently a phenomenon that is still considered taboo by some people because this divorce indicates that the meanings contained in a marriage are not carried out properly. The purpose this article is to describe the public perception of the problems that occur in the family as a trigger for divorce and to analyze people's perceptions of the number of divorce cases at present. This paper uses a qualitative approach with a case study method, with data collection in the form of interviews with informants, literature studies, and documentation studies. The results of the study show that some people perceive divorce as something that is not good, especially the case of divorce filed by the wife. There is still a label in the community which shows that women must act according to their nature, even though there are now many women working outside. The community reveals that marriage should be maintained so that the meaning of sacredness is maintained.
\end{abstract}

Keywords: Divorce, Perception, Society

\section{PENDAHULUAN}

Isue tentang perceraian menarik untuk dikaji,fenomena ini masih belum secara efektif ditemukan solusi atau cara pencegahannya. Perceraian sendiri merupakan bentuk kegagalan keluarga dalam mempertahankan keharmonisan di dalam keluarga. Saat ini, perceraian yang merupakan kegagalan dalam membina kerukunan keluarga sudah menjadi hal yang biasa bahkan bukan lagi menghambat suatu aktivitas (Darwanti, 2017), sehingga perceraian saat ini dipandang sebagai solusi terbaik ketika keluarga sudah rapuh. Keadaan tersebut 
berbeda dengan dulu, di mana masyarakat akan merasa malu karena perceraian adalah aib dan pemberi contoh yang buruk di lingkungan sosialnya. Kegagalan dalam rumah tangga yang dianggap lumrah ini berdasarkan fakta bahwa nilai kesejahteraan dalam keluarga saat ini masih belum dirasakan semua orang.

Gugatan cerai tersebut di dominasi oleh wanita yang merasa kurang puas dengan keadaan rumah tangganya. Jones menyebutkan bahwa banyak faktor yang menyebabkan wanita bekerja, yang diantaranya adalah untuk meningkatkan taraf hidup; perubahan dalam perceraian; jaminan sosial dan peraturan perpajakan; perubahan sikap gender; ketersediaan tabungan untuk membeli peralatan rumah tangga; dan mengurangi kesenjangan pendapatan antara suami dan istri (dalam Wijayanti \& Indrawati, 2016).

Dalam hal ini, muncul beberapa persepsi masyarakat mengenai gugat cerai yang berkaitan dengan ketidakmampuan pasangan dalam menjaga keharmonisan keluarga, terutama perempuan. Bekerjanya seorang perempuan di luar rumah dan kurangnya mengurus pekerjaan rumah tangga banyak menuai persepsi di masyarakat. Selain itu, saat ini tidak sedikit seorang suami yang mengurus rumah tangga dan jam kerjanya lebih sedikit dibandingkan seorang istri. Walaupun keadaan yang membuat perempuan saat ini banyak bekerja di luar rumah, tetapi tetap membuat persepsi yang diberikan masyarakat berbeda-beda. Masyarakat akan memperhatikan bagaimana seorang perempuan dapat mengurus rumah tangga, walaupun perempuan tersebut melakukan pekerjaan di luar rumah juga. Dalam tulisan ini, penulis akan menggunakan teori labelling berdasarkan pada pemikiran Erving Goffman yang menjelaskan labeling adalah pemberian label atau penamaan label yang berdasarkan atas perbedaanperbedaan yang dimiliki anggota masyarakat tersebut yang secara sosial tidak dianggap relevan sehingga terlihat menonjol. (Amanda, 2017).

Berdasarkan pemaparan di atas, labeling merupakan sesuatu pelabelan yang diberikan kepada seseorang karena perbedaan dengan kondisi sosial lingkungan masyarakat. Pelabelan ini terjadi berdasarkan persepsi atau stigma masyarakat yang diberikan kepada seseorang terkait dengan tindakan dan perilakunya.
Teori labeling ini melihat fakta bahwa terkadang ada seseorang atau bahkan kelompok orang yang menjadi objek interpretasi masyarakat yang di mana identitas sosial mereka dapat dipengaruhi yang berbeda pendapat dengan masyarakat lainnya (Amanda, 2017). Dalam fenomena perceraian ini yang digugat oleh wanita ini, wanita sudah menyadari keberadaannya yang berbeda di masyarakat, karena menurut sebagian masyarakat perceraian merupakan sebuah hal yang tabu dan tidak baik, yang memperlihatkan bahwa sebuah kesakralan dalam sebuah pernikahan sudah mulai menurun. Sedangkan perceraian saat ini dilakukan berdasarkan berbagai pengalaman perempuan yang mengajukan cerai adalah sebagai solusi terbaik apabila dalam permasalahan rumah tangga tidak menemukan titik temu.

Kajian ini mencoba untuk menganalisis persepsi masyarakat mengenai perceraian, antara lain mengenai masalah pemicu perceraian, serta persepsi mengenai kasus gugat cerai. Ketertarikan untuk mengkaji persepsi masyarakat mengenai perceraian ini dikarenakan saat ini kasus perceraian banyak dijumpai dengan jumlah yang tidak sedikit di berbagai daerah, terutama kasus gugat cerai. Dengan kondisi demikian, maka ingin dilihat berbagai persepsi masyarakat di Kabupaten Ciamis mengenai perceraian.

Kajian dilakukan terhadap perceraian ini memfokuskan pada "Bagaimana persepsi masyarakat mengenai banyaknya kasus perceraian saat ini?”

\section{METODE}

Metode yang akan digunakan dalam artikel ini adalah metode kualitatif dengan menggunakan strategi penelitian studi kasus untuk mengkaji secara lebih mendalam dan menggali persepsi masyarakat secara detail. Penulis akan melihat berbagai persepsi masyarakat, baik dari perspektif perempuan, laki-laki, maupun anak korban dari perceraian orang tua mengenai kasus perceraian yang terjadi saat ini. Penulis melakukan wawancara semistruktur kepada 11 informan, yang terdiri dari 5 orang laki-laki, 6 orang perempuan yang dua di antaranya adalah anak dari orang tua yang bercerai. 


\begin{tabular}{|c|c|c|c|c|}
\hline Share: Social Work Jurnal & VOLUME: 9 & NOMOR: 1 & HALAMAN: 20-27 & $\begin{array}{c}\text { ISSN:2339-0042 (p) } \\
\text { ISSN: 2528-1577(e) } \\
\text { Doi: 10.24198/share.v9i1.19863 }\end{array}$ \\
\hline
\end{tabular}

Penulis memilih lokasi penelitian di Kabupaten Ciamis berdasarkan pertimbangan bahwa (1) Banyaknya perceraian saat ini tidak hanya terjadi di perkotaan saja, tetapi telah menjalar sampai ke daerah yang tingkat kesejahteraannya masih kurang. (2) Kabupaten Ciamis merupakan salah satu penyumpang perceraian terbanyak karena perekonomian di Jawa Barat. (3) Selama ini, jarang terekspos Kabupaten Ciamis sebagai salah satu penyumbang perceraian terbanyak di Jawa Barat, sehingga menarik untuk mengkaji persepsi dan pengetahuan masyarakat mengenai kasus perceraian di Kabupaten Ciamis ini.

Dalam pengumpulan data penulis melakukan studi litelatur sebagai bahan acuan dalam menjelaskan kajian-kajian teoritis yang diperoleh dalam buku-buku, jurnal-jurnal, serta sumber lainnya yang berkaitan dengan persepsi masyarakat mengenai perceraian. Kemudian, akan menggunakan studi dokumentasi sebagai informasi pendukung berupa data tentang tingkat perceraian dan penyebab perceraian.

Analisis data yang akan digunakan yakni, reduksi data pemilahan informasi yang dianggap penting dan kemudian dirangkum, penyajian data berupa penyusunan hasil rangkuman dalam sebuah deskripsi singkat sehingga dapat ditarik kesimpulan. Tahap terakhir adalah penarikan kesimpulan dengan memverifikasi data yang telah dikumpulkan untuk menjadi bahan pembuatan tulisan artikel.

\section{HASIL DAN PEMBAHASAN}

Perceraian secara umum merupakan terputusnya hubungan dalam keluarga karena salah satu atau kedua pasangan tersebut memutuskan untuk hidup terpisah dan saling meninggalkan sehingga mereka berhenti melakukan kewajibannya sebagai suami istri (Lestari, 2016). Maraknya isu perceraian saat ini merupakan kegagalan suami-istri dalam menjaga ketahaan dan keutuhan keluarga.

Perceraian masih merupakan hal tabu di masyarakat sehingga menimbulkan persepsi tidak baik di masyarakat. Goode; 2014) mengungkapkan adanya berbagai persepsi pada perceraian ini adalah gejala adanya berbagai perubahan lainnya dalam masyarakat, yaitu: (1) Ha ini ada kaitannya dengan perubahan nilai dan norma tentang perceraian itu sendiri (2) telah adanya perubahan pada tekanan-tekanan sosial yang berasal dari lingkungan keluarga atau kerabat, teman-teman dan lingkungan tetangga yang berpengaruh terhadap ketahanan sebuah perkawinan (3) Peralihan fungsi-fungsi keluarga kepada lembaga lainnya di luar keluarga (4) adanya kesamaan derajat dan tuntutan persamaan hak antara laki-laki dan perempuan dan (5) semakin menguatnya sikap individualis dan menjadikan persoalan rumah tangga adalah urusan pribadi (Fachrina \& Putra, 2013). Kelima hal tersebut merupakan dampak dari perubahan sosial yang sebenarnya dapat memajukan masyarakat, namun di sisi lain menimbulkan dampak negatif berupa perceraian yang bahkan saat ini permasalahan tersebut diabaikan di masyarakat. Jumlah fenomena perceraian di Indonesia terlihat berdasarkan data dari Pengadilan Tinggi Agama Jawa Barat dalam kurun waktu 3 tahun (20162018) sebagai berikut:

\section{Grafik 1.}

\section{Jumlah Perceraian di Kabupaten Ciamis}

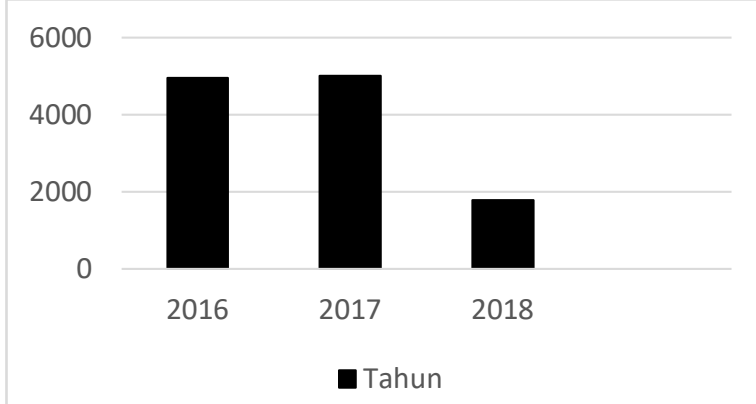

Sumber:, diolah

Dalam data tersebut, di perkara perceraian yang masuk di Pengadilan Kabupaten Ciamis tahun 2016 sekitar ada 4.957 ribu masyarakat yang bercerai, tahun 2017 ada 5.008 ribu dan tahun 2018, dari bulan Januari-April ada 1.792 ribu masyarakat yang mengajukan perceraian. Terlihat terjadi peningkatan setiap tahunnya, di mana perceraian di dominasi oleh perempuan. Walaupun keluarga sebagai institusi terkecil dalam masyarakat apabila dibiarkan akan berkelanjutan. Sejatinya, keluarga adalah benteng terakhir peradaban ketika negara dinilai gagal membangun peradaban (Sahlan, 2012). Apabila diakumulasikan, perbandingan pengajuan cerai antara laki-laki dan perempuan setiap tahunnya sebagai berikut: 


\begin{tabular}{|c|c|c|c|c|}
\hline Share: Social Work Jurnal & VOLUME: 9 & NOMOR: 1 & HALAMAN: $20-27$ & $\begin{array}{c}\text { ISSN:2339-0042 (p) } \\
\text { ISSN: } 2528-1577(e) \\
\text { Doi: } 10.24198 / \text { share.v9i1.19863 }\end{array}$ \\
\hline
\end{tabular}

Tabel 1.

Perbandingan Jumlah Pengajuan Perceraian di Ciamis

\begin{tabular}{|l|c|c|c|}
\hline Perceraian & $\mathbf{2 0 1 6}$ & $\mathbf{2 0 1 7}$ & $\begin{array}{c}\mathbf{2 0 1 8} \\
\text { (Jan- } \\
\text { April) }\end{array}$ \\
\hline $\begin{array}{l}\text { Cerai Talak } \\
\text { (Laki-laki) }\end{array}$ & 1.674 & 1.645 & 553 \\
\hline $\begin{array}{l}\text { Cerai Gugat } \\
\text { (Perempuan) }\end{array}$ & 3.116 & 3.144 & 1.147 \\
\hline
\end{tabular}

Sumber : Dokumen Pengadilan Tinggi Agama

Jawa Barat 2016-2018, diolah

Informan dalam penelitian ini merupakan masyarakat di Kabupaten Ciamis yang mempunyai persepsi yang berbeda-beda mengenai perceraian yang terjadi saat ini. Selain itu, yang menjadi informan adalah 2 orang wanita yang merupakan anak dari korban orangtua yang bercerai yang mengalami dampak secara langsung sehingga memunculkan suatu persepsi sesuai dengan apa yang dialaminya. Untuk informan lainnya dalam penelitian ini adalah 5 orang laki-laki dan 4 orang perempuan agar dapat dilihat persepsi dari kedua belah pihak yang berbeda gender tersebut. Mereka terdiri dari 4 laki-laki yang sudah berumah tangga, 1 orang laki-laki dewasa yang belum berumah tangga, dan 4 orang perempuan yang sudah berumah tangga.

\section{Persepsi Masyarakat Mengenai Perceraian \\ a. Permasalahan dalam Keluarga sebagai Pemicu Perceraian}

Perceraian terjadi karena ada sebab-sebab yang melandasinya, baik itu perkara yang sudah lama namun belum terselesaikan ataupun perkara baru yang disebabkan oleh salah satu pasangan yang sudah tidak mempertahankan kondisi rumah tangganya. Ada berbagai faktor penyebab yang menjadi permasalahan dalam perceraian di Kabupaten Ciamis adalah sebagai berikut:
Tabel 2.

Faktor Penyebab Perceraian di Kabupaten Ciamis

\begin{tabular}{|l|c|c|c|}
\hline \multicolumn{1}{|c|}{ Perceraian } & $\mathbf{2 0 1 6}$ & $\mathbf{2 0 1 7}$ & $\begin{array}{c}\mathbf{2 0 1 8} \\
\text { (Jan-April) }\end{array}$ \\
\hline Krisis Akhlak & 28 & & 51 \\
\hline Mabuk & - & 1 & 1 \\
\hline Zina & - & - & 158 \\
\hline $\begin{array}{l}\text { Meninggalkan salah } \\
\text { satu pihak }\end{array}$ & - & 32 & 2 \\
\hline Poligami & - & 112 & 4 \\
\hline $\begin{array}{l}\text { Kekerasan dalam } \\
\text { rumah tangga }\end{array}$ & - & 39 & 1.341 \\
\hline $\begin{array}{l}\text { Ekonomi } \\
\text { Perselisihan dan } \\
\begin{array}{l}\text { Pertengkaran terus } \\
\text { menerus }\end{array}\end{array}$ & 758 & 373 & 128 \\
\hline Lain-Lain & - & 232 & - \\
\hline
\end{tabular}

Sumber : Dokumen Pengadilan Tinggi Agama Jawa Barat 2016-2018, diolah

Dalam data tersebut terllihat bahwa penyebab utama perceraian yang terjadi disebabkan oleh faktor ekonomi yang mendominasi gugat cerai yang dilakukan oleh perempuan. Saat ini, tingkat perekonomian semakin meningkat karena tuntutan zaman, oleh karena itu setiap keluarga ingin hidup sejahtera dan mengharapkan suami dapat memenuhi segala kebutuhan rumah tangga, namun sebaliknya yang terjadi saat ini suami bekerja serabutan dan menyebabkan perubahan pada pola pikir wanita yang ingin maju. Berikut ini merupakan perspektif masyarakat mengenai faktor-faktor yang menyebabkan perceraian:

\section{1) Makna Pernikahan}

Dalam pernikahan, terjadinya suatu penyatuan antara laki-laki dan perempuan dengan sifat dan karakter yang berbeda, latar belakang yang berbeda, sehingga apabila pasangan belum secara mantap siap lahir batin untuk menanggung segala resikonya, siap menjalani susah dan senangnya kehidupan sampai ajal memisahkan (Oktarina, Wijayaa, \& Demartoto, 2015), yang menjadi tantangan setiap pasangan. Bahkan hal tersebut menjadi seni dan tantangan yang harus dilewati pasangan terkait perbedaan-perbedaan di antara keduanya, namun pada intinya untuk menyatukan berbagai perbedaan-perbedaan tersebut harus mencari satu arah yang sama yang justru inilah kesulitan yang dialami setiap pasangan. 


\begin{tabular}{|c|c|c|c|c|}
\hline Share: Social Work Jurnal & VOLUME: 9 & NOMOR: 1 & HALAMAN: 20-27 & $\begin{array}{c}\text { ISSN:2339-0042 (p) } \\
\text { ISSN: 2528-1577(e) } \\
\text { Doi: 10.24198/share.v9i1.19863 }\end{array}$ \\
\hline
\end{tabular}

Di Indonesia berkembang dua makna umum tentang perkawinan, yaitu perkawinan dengan makna konvensional dan perkawinan yang bermakna modern (pilihan rasional) (Oktarina, Wijayaa, \& Demartoto, 2015). Dalam makna konvensional, pernikahan membatasi ruang gerak perempuan yang masih mengikuti aturan atau tuntutan sosial di masyarakat. Dalam makna secara pilihan rasional, adanya suatu proses yang dilalui individu atas dasar pilihan atau kriteria tertentu. Pernikahan itu memiliki makna yang sangat sakral. Pernikahan merupakan proses mempersatukan dua hati yang berbeda dengan berjanji untuk setia seumur hidup. Pernikahan ini dipegang teguh sebagai sesuatu yang bernilai sangat berharga dan harus sudah siap lahir dijalani oleh setiap pasangan. Setiap pasangan harus berjalan beriringan agar tercapainya keluarga yang utuh dan kuat.

Namun, apabila ditinjau mengenai banyaknya kasus perceraian saat ini, terlihat bahwa adanya suatu ketidaksiapan pasangan dalam berumah tangga. Adanya sikap tidak menghargai sebuah pernikahan sehingga inilah awal mula dari permasalahan yang muncul dalam keluarga. Menurunnya nilai-nilai sakral dalam setiap pasangan sehingga tidak dapat mempertahankan pernikahannya akibat konflikkonflik yang masih dapat diselesaikan secara damai oleh kedua belah pihak. Hal seperti ini memperlihatkan bahwa makna pernikahan tidak lagi dipandang sebagai sesuatu yang harus dipertahankan seumur hidup oleh sebagian pasangan, diiringi dengan ketidaksiapan dan minimnya pengetahuan mengenai sikap dan perilaku pasangan masing-masing. Artinya, kedua pasangan belum secara matang mengetahui sifat-sifat asli.

\section{2) Ekonomi}

Permasalahan ekonomi merupakan permasalahan umum yang terjadi saat ini di masyarakat terkait dengan banyaknya kasus perceraian. Permasalahan ekonomi ini biasanya dipicu oleh ketidakmampuan laki-laki dalam memenuhi dan mengembangkan tingkat perekonomian keluarga. Faktor yang mendominasi perceraian saat ini diantaranya adalah faktor ekonomi yang sering kali menjadi pokok permasalahan yang dihadapi oleh pasangan suami istri yang mengalami pra perceraian (Wijaya, 2015).
Hal tersebut berbanding terbalik dengan seorang istri yang saat ini sudah banyak bekerja di luar rumah, bahkan sebagian jam kerjanya dan tingkat penghasilannya melebihi suami. Hal ini kemudian yang menjadi pertimbangan wanita dalam menggugat cerai suaminya, di mana kebutuhan semakin lama semakin meningkat namun seorang suami tidak dapat mencapai taraf kebutuhan yang diperlukan saat ini. Kurangnya jiwa "altruism” suami terhadap seorang istri (Puspitawati, 2013) yang menyebabkan sebagian suami bahkan ada yang tidak bekerja dan bergantung pada pekerjaan istri.

Wanita sebagai seorang istri ingin dipenuhi segala kebutuhan hidupnya dan tidak bergantung pada penghasilan suami. Hal tersebut dilandasi oleh pola pikir pragmatisme, yang menjadikan pernikahan tidak lagi sebagai lahan ibadah, tetapi sebagai hubungan transaksional yang secara financial, lebih senang, lebih bahagia, yang mana kalau hal itu tidak tercapai, maka perceraian dianggap sebagai jalan yang terbaik (Andaryuni, 2017). Sebagian suami bekerja di rumah yang mengurus keperluan rumah tangga. Hal tersebut terjadi karena saat ini semakin sulitnya lahan pekerjaan yang layak didapatkan oleh setiap orang. Persaingan yang semakin banyak membuat laki-laki kesulitan dalam mencari pekerjaan yang layak. Sehingga dalam hal ini, ekonomi mejadi permasalahan yang paling banyak, terutama pada kasus perceraian di Kabupaten Ciamis.

\section{3) Ketidakharmonisan dalam Keluarga}

Masyarakat mempresepsikan bahwa ketidakharmonisan kedua pasangan karena perselingkuhan yang memicu konflik dan perselisihan secara terus menerus dalam keluarga. Masyarakat menganggap bahwa perselingkuhan ini dilakukan oleh laki-laki, namun tidak menutup kemungkinan wanita juga melakukan hal seperti itu. Dalam hal ini, perempuan lebih banyak berinisiatif mengajukan gugatan cerai karena ketika terjadi konflik, perempuan lebih merasakan konflik dan dampaknya (Nurhasanah \& Rozalinda, 2014).

Perselingkuhan ini bermula dari media sosial yang digunakan sehari-hari sebagai pemicu utama. Telah banyaknya media sosial 
yang digunakan saat ini, seperti facebook dan whats up, banyak dimiliki tidak oleh hanya anak muda saja, tetapi para kaum wanita-wanita dewasa, bahkan yang sudah berumur sekalipun. Namun, semua itu kembali pada pasangan masing-masing. Apabila memiliki pondasi agama yang kuat serta komitmen yang serius pada awal pernikahan, hal seperti ini akan dapat terhindarkan.

Selain itu, tidak jarang juga kasus KDRT yang dialami oleh istri dalam rumah tangga yang menjadi pemicu perceraian lainnya. Sikap suami yang kasar tersebut menimbulkan luka yang cukup mendalam bagi wanita, sehingga perceraian ini sebagai solusi terbaik agar wanita dapat hidup dengan damai dan tenang dengan anak-anak mereka. Selanjutnya, karena faktor ketidakcocokan dari kedua pasangan yang sudah saling berbeda prinsip dan pandangan sehingga memungkinkan kedua pasangan saling bersepakat untuk mengakhiri pernikahan mereka.

Brooks menjelaskan bahwa saat terjadinya perceraian orang tua, anak memberikan reaksi emosional yang mana hal ini biasa terjadi pada anak semua usia, mencakup kesedihan, ketakutan, depresi, amarah, dan kebingungan (Hadianti, Nurwati, \& Darwis, 2017). Walaupun demikian, seiiring berjalannya waktu anak menyesuaikan diri dan dapat menerima keadaan kedua orang tuanya.

\section{b. Persepsi Masyarakat terhadap Banyaknya Kasus Perceraian}

Perceraian saat ini masih dianggap tabu dan bukanlah sesuatu hal yang baik di lingkungan masyarakat, baik dari perspektif laki-laki maupun wanita, walaupun pada kenyataannya itu dapat dikembalikan lagi pada keadaan kedua pasangan, tetapi tetap saja tidak sesuai dengan tujuan pernikahan sendiri, di mana masyarakat harapannya adalah menikah satu kali seumur hidup. Perceraian yang semakin banyak ini menunjukan adanya derajat pertentangan yang tinggi antara suami-istri dan memutuskan ikatan yang semula mengingat dua turunan keluarga. (Goode, 2004)

Perceraian seharusnya sesuatu yang dapat dihindari dan sebisa mungkin kedua pasangan dapat mempertahankan pernikahan mereka. Masalah yang masih dirasa bisa diatasi misalnya menyangkut masalah perilaku atau kebiasaan buruk pasangan, kurangnya perhatian kepada pasangan, suami jarang di rumah, mudah emosi, sikap mementingkan diri sendiri dan tidak saling menghargai (Fachina \& Putra, 2013). Permasalahan tersebut masih dapat ditrundingkan dan dapat di toleransi, ada baiknya untuk dipertahankan. Kecuali memang dalam keluarga adanya sesuatu kesalahan yang tidak dapat di toleransi seperti kekerasan dalam rumah tangga (KDRT), dan perselingkuhan.

Kasus perceraian yang menonjol saat ini adalah kasus cerai gugat yang dianggap sebagai sesuatu yang tidak baik walaupun akhirnya dikembalikan kepada kondisi keluarga masingmasing pasangan yang bercerai. Dari perspektif laki-laki, banyak berbagai faktor yang menyebabkan seorang istri akhirnya dapat menggugat cerai suaminya, sehingga suami pada akhirnya akan pasrah dengan keputusan pengadilan, walaupun akhirnya keputusan bercerai kembali lagi atas dasar persetujuan laki-laki.

Dalam pandangan laki-laki, istri yang menggugat cerai suami dianggap sebagai hal yang buruk karena berani menggugat cerai suami. Apabila dari sudut pandang perempuan dan anak sendiri hal tersebut berkaitan dengan perubahan sikap dari diri perempuan yang saat ini telah bekerja di luar rumah karena tanggung jawab keluarga, pola konsumsi, persiapan pendidikan, hak-hak hukum, serta kesempatan kerja (Ollenburger \& Moore, 2002). Sehingga, perempuan telah berani menggugat cerai lakilaki karena telah merasa mampu dan bisa hidup mandiri tanpa tergantung pada suami yang dianggap tidak mampu menyejahterakan perempuan.

Namun, bagaimanapun alasannya tetap cerai gugat merupakan sesuatu yang menyalahi kodrat sebagai perempuan bagi masyarakat, adanya pemberian label tersebut memojokan kaum perempuan, sehingga berakibat kepada posisi dan kondisi kaum perempuan (Fakih, 2012). Pemberian label tersebut diberikan oleh masyarakat karena memang stereotipe terhadap perempuan yang dibentuk oleh masyarakat masih ada sampai saat ini. Walaupun label tersebut tidak ditunjukan secara terangterangan, namun persepsi di masyarakat berkembang berdasarkan pemahaman mereka 


\begin{tabular}{|c|c|c|c|c|}
\hline Share: Social Work Jurnal & VOLUME: 9 & NOMOR: 1 & HALAMAN: 20-27 & $\begin{array}{c}\text { ISSN:2339 }-0042(p) \\
\text { ISSN: 2528-1577 }(e) \\
\text { Doi: 10.24198/share.v9i1.19863 }\end{array}$ \\
\hline
\end{tabular}

mengenai perempuan yang seharusnya bersikap menurut pada suami.

\section{KESIMPULAN}

Banyaknya perceraian yang terjadi saat ini sebagai akibat dari telah melemahnya nilainilai pernikahan dan perceraian, di mana saat ini perceraian merupakan hal yang biasa yang dijadikan solusi terkait permasalahan dalam keluarga. Hal tersebut menimbulkan berbagai persepsi di masyarakat terkait maraknya fenomena perceraian. Berikut ini merupakan simpulan berdasarkan hasil pembahasan :

1. Persepsi masyarakat terkait dengan permasalahan keluarga pemicu perceraian saat ini berkaitan dengan makna pernikahan, dimana telah menurunnya nilai-nilai sakral dalam pernikahan sehingga kedua pasangan sepakat untuk melakukan perceraian. Selanjutnya berkaitan dengan faktor ekonomi yang menjadi penyebab utama terpicunya perceraian di mana suami tidak dapat sepenuhnya memenuhi kebutuhan dalam keluarga. Kemudian terkait dengan ketidakharmonisan menjadi pemicu dalam hubungan rumah tangga yang disebabkan oleh pertengkaran secara terus menerus disertai dengan perselingkuhan yang dilakukan oleh pasangan.

2. Persepsi masyarakat terkait dengan perceraian saat ini yang membahas mengenai persepsi masyarakat mengenai kasus gugat cerai istri yang melabelkan bahwa hal tersebut merupakan hal yang tidak baik dan negatif, hal tersebut berdasarkan pemahaman masyarakat bahwa perempuan seharusnya bersikap menurut pada suami.

\section{DAFTAR PUSTAKA}

\section{Buku}

Fakih, M. 2012. Analisis Gender dan Transformasi Sosial. Yogyakarta : Insist Press.

Goode, W.J. 2004. Sosiologi Keluarga. Jakarta : Bumi Aksara.

Ollenburger, J.C., \& Moore, H.A. 2002 Sosiologi Wanita. Jakarta : Rineka Cipta.
Puspitawati, H. 2017. Gender dan Keluarga. Bogor : IPB Press.

\section{Jurnal}

Andaryuni, L. 2017. Pemahaman Gender Dan Tingginya Angka Cerai Gugat Di Pengadilan Agama Samarinda. Fenomena, 9(1), h. 155-174.

Darwanti. 2017. Perceraian Dalam Perspektif Sosiologi. Sulesana, 11(1), 65-78.

Fachrina \& Putra, R.E. 2013. Upaya Pencegahan Perceraian Berbasis Keluarga Luas dan Institusi Lokal dalam Masyarakat Minangkabau di Sumatera Barat. Antropologi Indonesia, 34(2), h. 101-112.

Hadianti, S.W., Nurwati, N., \& Darwis, R.S. 2017. Resiliensi Remaja Berprestasi Dengan Latar Belakang Orang Tua Bercerai Studi Kasus Pada Siswa - Siswi Berprestasi Dengan Latar Belakang Orang Tua Bercerai Di Sma Negeri 1 Margahayu. Jurnal Penelitian \& PKM, 4(2), h. 129 - 389.

Lestari, K. 2016. Perceraian Keluarga Pegawai Negeri Sipil (PNS) (Studi Kasus Kecamatan Bangko Kabupaten Rokan Hilir Provinsi Riau). JOM FISIP, 3(1), hlm. 1-15.

Nurhasanah \& Rozalinda. 2014. Persepsi Perempuan Terhadap Perceraian: Studi Analisis Terhadap Meningkatnya Angka Gugatan Cerai di Pengadilan Agama Padang. Kafa'ah: Jurnal Ilmiah Kajian Gender, 4(2), h. 181-201.

Oktarina, L.P, Wijaya, M, \& Demartoto, A. (2015). Pemaknaan Perkawinan: Studi Kasus Pada Perempuan lajang Yang Bekerja Di Kecamatan Bulukerto Kabupaten Wonogiri. Jurnal Analisa Sosiologi, 4(1), h. 75 -90.

Sahlan, M. 2012. "Pengamatan Sosiologis Tentang Perceraian di Aceh”. Jurnal Substantia, 14(1), hlm. 88-97.

Wijayanti, A.T \& Indrawati, E. S. 2016. Hubungan antara Konflik Peran Ganda dengan Kepuasan Pernikahan pada Wanita yang Bekerja sebagai Penyuluh di Kabupaten Purbalingga. Jurnal Empati UNDIP, 5 (2), hlm. 282-286. 


\begin{tabular}{|c|c|c|c|c|}
\hline Share: Social Work Jurnal & VOLUME: 9 & NOMOR: 1 & HALAMAN: 20-27 & $\begin{array}{c}\text { ISSN:2339 -0042 (p) } \\
\text { ISSN: 2528-1577 }(e) \\
\text { Doi: } 10.24198 / \text { share.v9i1.19863 }\end{array}$ \\
\hline
\end{tabular}

Wijaya, M. R. 2015. Dramaturgi Pra Perceraian Remaja (Studi di Kabupaten Paser Kecamatan Tanah Grogot). SosioantriSosiologi, 3(4), 1-10.

\section{Skripsi}

Amanda, S.D. 2017. Strategi Adaptasi Kepala Rumah Tangga Perempuan Pasca Bercerai Di Kota Kediri. Semarang : Universitas Airlangga.

Dokumen:

Pengadilan Tinggi Agama Jawa Barat 20162018. Laporan Tahunan. Bandung. 